\title{
Investigation of Antibacterial and Cytotoxic Properties of Mix Ligand Complex of Zinc 2-Fluorobenzoate with Nicotinamide
}

\author{
Cem Ozturk ${ }^{1}$, Giray Bugra Akbaba ${ }^{1}$ \\ ${ }^{1}$ Kafkas University, Department of Bioengineering, Kars, Turkey
}

\section{ABSTRACT}

T $\mathrm{n}$ this study, antibacterial properties of the previously synthesized zinc 2-fluorobenzo-

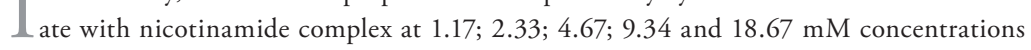
was investigated using by agar well diffusion method against Bacillus subtilis, Psedomonasa eruginosa, Staphylococcus aureus, Escherichia coli, Bacillus cereus and Klebsiella pneumoniae bacterias. The MTT method was used to determine the cytotoxic properties of the complex on human peripheral blood cells at the same concentrations. According to the results of the antibacterial study, it was determined that the complex showed a good antibacterial effect on all bacteria at 18.67 and $9.34 \mathrm{mM}$ concentrations. The complex exhibits to have a suppressive effect only on $S$. aureus bacteria at a concentration of $2.33 \mathrm{mM}$. It was observed that the complex was antibacterial on all bacteria except B. cereus and E. coli at a concentration of $4.67 \mathrm{mM}$. The complex was found to have no growth inhibiting effect on any bacteria at a concentration of $1.17 \mathrm{mM}$. The cytotoxicity of the complex was investigated by MTT test method and it was determined that the cell viability decreased due to increasing concentration according to the test results. Cell viability at $1.17 ; 2.33 ; 4.67 ; 9.34$ and 18.67 $\mathrm{mM}$ was determined to be $86.20 \%, 86.05 \%, 72.87 \%, 64.77 \%$ and $6.42 \%$, respectively.

\author{
Article History: \\ Received: 2019/08/23 \\ Accepted: 2019/10/25 \\ Online: 2019/12/31 \\ Correspondence to: Giray Bugra Akbaba, \\ Department of Bioengineering, Kafkas \\ University, 36100, Kars, Turkey \\ E-mail:gbugraakbaba@hotmail.com \\ Phone: +90 4742251150 , \\ Fax: +90 4742251282
}

Keywords:

Zinc complexes, Antibacterial activity, MTT, Cytotoxicity, Antibiotics

\section{INTRODUCTION}

$\mathrm{T}$ he purpose of crystal engineering is to explore new materials with striking properties that can be used in a variety of implementation areas. Metal complexes with an important place in crystal engineering consist of anions or molecules called ligands, which bind to a metal cation and metal atom at the center of symmetry. Metal complexes have been the subject of interest with the diversity of their structures for many years. The structures of metal complexes were determined to be influenced by the biological and physical properties of metal cations, ligands and intermolecular interactions [1-4]. Medical inorganic chemistry, which has an important place in materials science, is a multidisciplinary field consisting of chemistry, pharmacology, toxicology, and biochemistry. Medical chemists focus on the design and synthesis of new metal-based molecules with greater enhanced biological activity, better selectivity, low toxicity and multiple roles of mechanical effects to overcome the clinical problems of commercially available drugs due to their side effects. Metal complexes are growth inhibitors of bacteria, which is supported by in vitro and in vivo studies $[5,6]$.

Carboxylic acids have many biological activities such as anti-inflammatory, antibacterial and antifungal. In dermatology, the sodium salt of benzoic acid is used as an antifungal agent. The antibacterial activity of carboxylic acids can be increased by forming complexes with metal ions. The anti-inflammatory and antibacterial activity of metal complexes was determined to be greater than free acid. Therefore, it is crucial to learn about the structure and binding relationships of complexes in the preparation of effective antibacterial species. However, activity is also known to decrease in some similar complexes. Recently, studies on antimicrobial activity of non-steroid anti-inflammatory drugs have shown that the complexes of transition metals 
with various nitrogen-containing ligands show increased antimicrobial activity [7, 8]. Various metal complexes accelerate the effect of the drugs and organic therapeutics. Cobalt (II) mefenamic acid, naproxen, or tolfenamic acid [9-11] and mangan (II) tolfenamic acid complexes [12], copper (II) mefenamic acid, naproxen, diclofenac, diflunisal, and flufenamic acid complexes [13-15] exhibit biological activity. Zinc complexes with biologically active ligands have pharmaceutical effects because they are able to catalyze enzymatic processes in biological systems. Aromatic carboxylates (such as Naproxen, Ibuprofen, Indometacin) and aliphatic carboxylates (such as Valproic Acid) of zinc complexes with nitrogen-based ligands have been synthesized and their antibacterial and antimalarial properties have been studied recently. Most of zinc carboxylates with N-, O-, S- donor ligands have also antibacterial activity [16-19].

In this study, the antibacterial activity of previously synthesized zinc 2-fluorobenzoate complexes with nicotinamide was determined against Bacillus subtilis, Pseudomonas Aeruginosa, Staphylococcus aureus, Escherichia coli, Bacillus cereus and Klebsiella pneumoniae by agar well diffusion method. Cytotoxicity of the complex was studied using MTT test method.

\section{MATERIALS AND METHODS}

\section{Materials}

\section{Chemicals and Instruments}

The compound used in the study was a previously synthesized and its structure was determined. The molecular structure of the complex was given in Fig. 1. Mueller Hinton Agar (Oxoid), Phosphate Buffered Saline, Antibiotic Antimycotic Solution, L-Glutamine solution, Histopaque-1077 and Dimethylsulfoxide (Sigma-Aldrich), BIOAMF-1 medium and BIOAMF-1 supplement (Biological Industries) and MTT Cell Proliferation Assay Kit (Cayman Chemical) were purchased commercially. In this study, Nüve Steamart OT 40L autoclave, Nüve BM 101 Water bath, J.P. Selecta Digiheat drying and sterilization oven, ISOLAB vortex mixer, HETTICH EBA 200 centrifuge device, Panasonic MCO-170AICUVH-PE $\mathrm{CO}_{2}$ Incubator and BioTek Epoch Spectrophotometer were used.
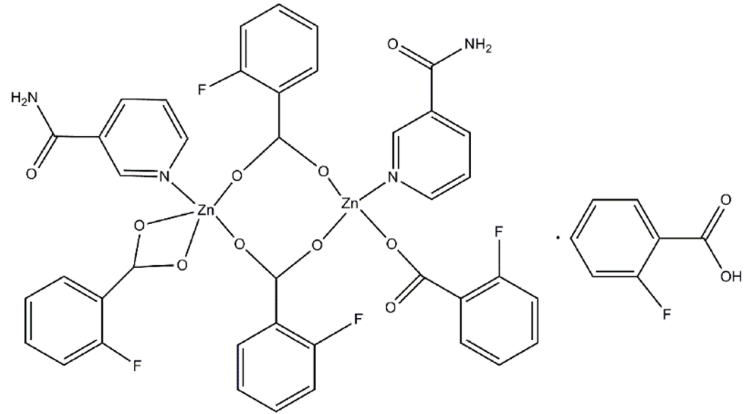

\section{Methods}

\section{Determination of Antibacterial Activity}

Agar well diffusion method was used to evaluate the antibacterial effects of different concentrations of the tested compound. B. subtilis (ATCC 6633), B. cereus (ATCC 8035), S. aureus (ATCC 25923), K. pneumoniae (ATCC 33499), P. aeruginosa (ATCC 27852) and E. coli (ATCC 259222) were used in the study. Bacteria were stored at 4 ${ }^{\circ} \mathrm{C}$ until they were used. For the preparation of the agar to be used, $38 \mathrm{~g}$ Mueller Hinton (MH) agar was boiled and mixed in $1 \mathrm{~L}$ distilled water until completely dissolved. The prepared agar solution was kept in an autoclave for 15 minutes at $121{ }^{\circ} \mathrm{C}$ for sterilization. The agar transferred to Petri dishes and was cooled at the room temperature. Dimethyl sulfoxide (DMSO) was used as a negative control group. The cultivation of microorganisms was done on the prepared agar. Then, $5 \mathrm{~mm}$ diameter wells were formed on the agar surface. $50 \mu \mathrm{L}$ of the tested compound were added to the wells. Petri dishes were incubated for 12 hours at $37^{\circ} \mathrm{C}$, and the diameter of the inhibition zone around each well was measured with the help of a ruler. The experiments were carried out in triplicate.

\section{MTT Analysis}

For the preparation of the culture medium, $75 \mathrm{~mL}$ of amnion cell culture medium, $15 \mathrm{~mL}$ of supplement, $1.5 \mathrm{~mL}$ of penicillin+streptomycin+amphotericin B (Antibiotic Antimycotic Solution) and $2 \mathrm{~mL}$ of L-glutamine were added in a sterile tube and kept at $37^{\circ} \mathrm{C}$. Lymphocytes were isolated from a human peripheral blood sample and cell counting was performed using a Thoma slide. After that $100 \mu \mathrm{L}$ culture medium and $100 \mu \mathrm{L}$ cell suspension (50000 cells/well) were added to the 96 -well plates, respectively. The microplate was kept for 24 hours in 5\% $\mathrm{CO}_{2}$ incubator at $37{ }^{\circ} \mathrm{C}$, allowing the cells to proliferate and adherence to the surface. After the incubation period was complete, $100 \mu \mathrm{L}$ aliquots of different concentrations (1.17; $2.33 ; 4.67 ; 9.34$ and $18.67 \mathrm{mM}$ ) of the compound were added to the wells. The cells were incubated at $37^{\circ} \mathrm{C}$ for 24 hours in the incubator. When the incubation period was complete, $10 \mu \mathrm{L}$ of MTT reagent was added to each well. The plate was gently mixed on the shaker. The cells were incubated at $37{ }^{\circ} \mathrm{C}$ for 3-4 hours. After incubation, formazan formed in the cells was seen as crystals in the bottom of the wells. Then, $200 \mu \mathrm{L}$ DMSO was added to each well after the medium in the well was completely removed. It was kept in the incubator at $37^{\circ} \mathrm{C}$ for 24 hours to dissolve the formazan crystals. At the end of the incubation, the absorbance values were measured by spectrophotometer at $570 \mathrm{~nm}$.

Figure 1. Molecular structure of the test compound [20] 


\section{RESULTS}

\section{Antibacterial Activity}

Antimicrobial effects of zinc complex against Gram positive (Bacillus subtilis, Bacillus cereus, and Staphylococcus aureus) and Gram negative (Klebsiella pneumonia, Pseudomonas aeruginosa and Escherichia coli) bacterial species were evaluated, and the results were given in Table 1 and Fig. 2. The compound at the concentrations of 18.67 and $9.34 \mathrm{mM}$ was found to have antibacterial effects against all bacteria. It was found that the complex had no inhibitory effect on any bacteria at a concentration of $1.17 \mathrm{mM}$, meaning that the complex was not antibacterial at that concentration. At $2.33 \mathrm{mM}$ concentration, the complex exhibits to have a suppressive effect only against S. aureus bacteria. It was determined that the complex showed antibacterial effect in all bacterial species except B. cereus and $E$. coli bacteria at $4.67 \mathrm{mM}$. The inhibition zones formed are seen in Fig. 3.

\section{MTT Test}

The results of MTT assay were evaluated. The absorbance values were measured by spectrophotometer. The decrease in cell viability according to the cell control group was calculated and obtained the percent inhibition values (Fig. 4). The \% inhibition values were calculated according to the following formula and the obtained values are given in Table 2 and Fig. 4.

$$
\text { Percent inhibition }(\%)=\frac{C V C C-C V T C}{C V C C} \times 100
$$

$(\mathrm{CVCC}=$ Cell viability in cell control, $\mathrm{CVTC}=\mathrm{Cell}$ viability at test concentrations)

When the obtained values are examined, it is seen that cell viability decreases with increasing concentration. At the concentrations of $1.17 \mathrm{mM}, 2.33 \mathrm{mM}, 4.67 \mathrm{mM}$ and 9.34 $\mathrm{mM}$, cell viability decreased by $13.80 \%, 13.95 \%, 27.13 \%$ and $35.23 \%$, respectively. The cell death at $18.67 \mathrm{mM}$, the highest concentration we studied, was $93.58 \%$ and the highest cytotoxic effect was occurred at this concentration.

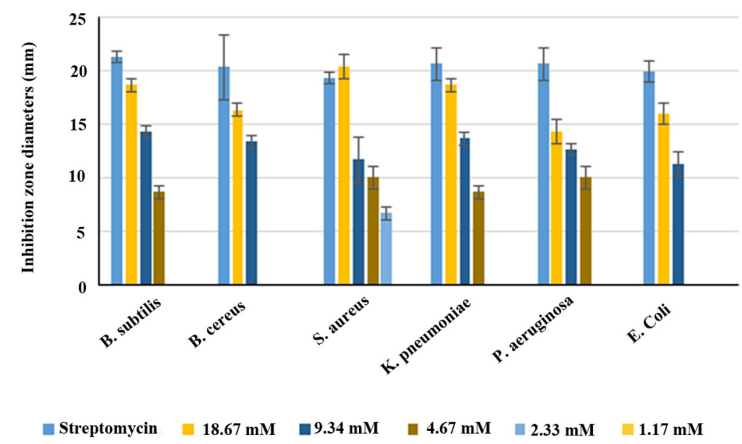

Figure 2. Comparison of inhibition zones in the studied concentrations

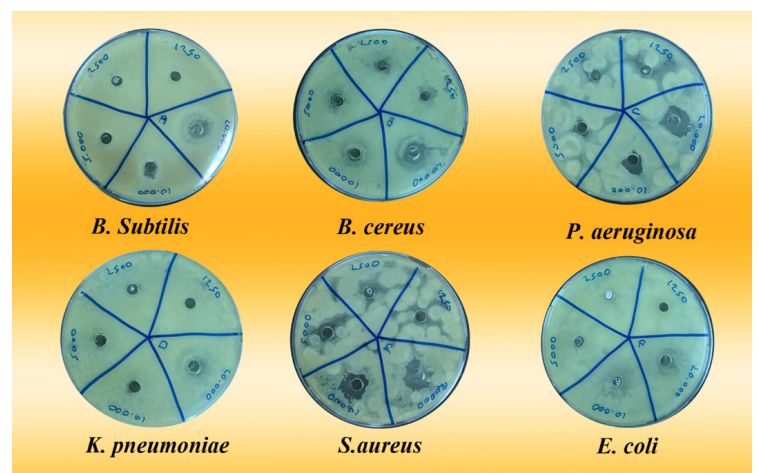

Figure 3. Inhibition zones formed by different concentrations of the tested compound

Table 2. Cell viability and inhibition values (\%)

\begin{tabular}{ccc}
\hline Concentrations & Cell Viability (\%) & Inhibition (\%) \\
\hline Cell Control & 100.00 & - \\
$1.17 \mathrm{mM}$ & 86.20 & 13.80 \\
$2.33 \mathrm{mM}$ & 86.05 & 13.95 \\
$4.67 \mathrm{mM}$ & 72.87 & 27.13 \\
$9.34 \mathrm{mM}$ & 64.77 & 35.23 \\
$18.67 \mathrm{mM}$ & 6.42 & 93.58 \\
\hline
\end{tabular}

Table 1. Antibacterial activity results

\begin{tabular}{|c|c|c|c|c|c|c|}
\hline \multicolumn{7}{|c|}{ Inhibition zone diameters ( $\mathrm{mm}$ ) } \\
\hline \multicolumn{4}{|c|}{ Gram Positive } & \multicolumn{3}{|c|}{ Gram Negative } \\
\hline Derişim & B. subtilis & B. cereus & S. aureus & K. pneumoniae & P. aeruginosa & E. coli \\
\hline $\begin{array}{c}\text { Streptomycin } \\
\left(5.16 \times 10^{-4} \mathrm{mM}\right)\end{array}$ & 21.33 & 20.33 & 19.33 & 20.67 & 20.67 & 20.00 \\
\hline $18.67 \mathrm{mM}$ & 18.67 & 16.33 & 20.33 & 18.67 & $14 \cdot 33$ & 16.00 \\
\hline $9.34 \mathrm{mM}$ & $14 \cdot 33$ & $13 \cdot 33$ & 11.67 & 13.67 & 12.67 & 11.33 \\
\hline $4.67 \mathrm{mM}$ & 8.67 & - & 10.00 & 8.67 & 10.00 & - \\
\hline $2.33 \mathrm{mM}$ & - & - & 6.67 & - & - & - \\
\hline $1.17 \mathrm{mM}$ & - & - & - & - & - & - \\
\hline DMSO & - & - & - & - & - & - \\
\hline
\end{tabular}




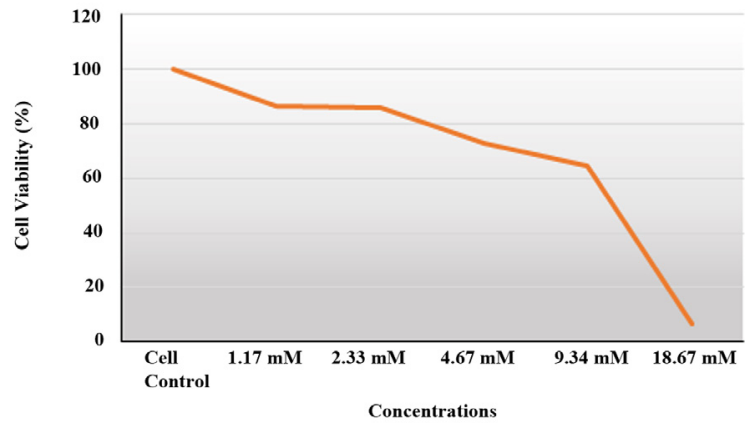

Figure 4. The percentages of cell viability

\section{DISCUSSION}

The antibacterial effect of zinc 2-fluorobenzoate nicotinamide complex at 1.17, 2.33, 4.67, 9.34 and $18.67 \mathrm{mM}$ concentrations against Bacillus cereus, Bacillus subtilis, Staphylococcus aureus, Pseudomonas aeruginosa, Escherichia coli and Klebsiella pneumoniae was studied by agar well diffusion method. Cytotoxic effect of the complex on human peripheral blood lymphocyte cultures was determined by MTT method in vitro conditions. In this section, obtained results were evaluated and compared with literature.

The synthesis of new compounds has gained importance in the pharmaceutical sector due to the resistance of bacteria to antibiotics. The biological activities of the synthesized compounds are also examined. However, advanced clinical trials are not possible for all compounds for reasons such as time and economy. The antibacterial activities and toxic properties of newly synthesized compounds need to be determined. Therefore, researchers have very big tasks. Because high antibacterial activity and low toxicity make the compound a more important drug material. In this context, metal complexes have an important place in drug chemistry.

Omar and Abu Ali studied the antibacterial effect of zinc ibuprofen's complexes with 4,4'-bipyridine, 1,10-phenanthroline, 2,9-dimethyl-1,10-phenanthroline, 1,2-dimethylimidazole, 1,2-dimimidazole, 2-dimethylimidazole, 2-amino-6-picoline [24] and Ali et al. studied the antibacterial effect of zinc ibuprofen's complexes with 2-aminopyridine, 2-aminomethylpyridine and 2,2'-bipyridine and 2-(Methylamino)pyridine against Micrococcus luteus, Staphylococcus aureus, Bacillus subtilis, Escherichia coli, Klebsiella pneumonia and Proteus mirabilis at 6 g.L-1 (6000 ppm) concentration [19]. Complexes with 4,4-bipyridine, 1,10-phenanthroline, 2,9-dimethyl-1,10-phenanthroline and 2,2-bipyridine were found to be effective on gram positive bacteria. These two studies show that the antibacterial effect may change depending on the metal and ligand used. The antibacterial effects of these compounds decrease as concentration decreases. There are no findings on toxi- city in the studies. Zinc complexes of naproxen, one of the nonsteroidal and anti-inflammatory drugs, have also been synthesized. Antibacterial effects of the complexes obtained using different pyridine derivatives were studied by disc diffusion method against Escherichia coli and Salmonella aureus and by agar well diffusion method for Staphylococcus aureus, Micrococcus luteus, Klebsiella pneumoniae, Pseudomonas aeruginosa, Proteus mirabilis and Escherichia coli. The complexes obtained in these studies were suggested as antibiotics. But the toxicity of the complexes was not investigated $[18,25]$.

The antibacterial properties of zinc coumarin-3carboxylate (100-1000 $\mu \mathrm{g} / \mathrm{mL})$ [26], zinc 5-iodo and 5-bromosalicylate $\left(0.001-200 \mathrm{mmol} . \mathrm{dm}^{-3}\right)$ [27], zinc 2-bromobenzoate $\left(0.01-2.0 \mathrm{mmol}^{-\mathrm{dm}^{-3}}\right)$ [28] and zinc salicylates $(1 \mathrm{mg} /$ $\mathrm{mL}$ ) [29] have been investigated. Although the main ligands has antibacterial activity, it has been reported that the antibacterial effect increases in some complexes (especially with pyridine derivatives). However, no additional studies have been carried out the toxicity of these compounds as well. In these studies, the importance of carboxylate complexes was emphasized related to their antibacterial properties. The most prominent feature that distinguishes our study from these studies was the antibacterial activity test as well as studying the cytotoxicity of the complex. In this study, it was determined that the compound has antibacterial properties according to inhibition zone diameters at the concentrations of $0.02 \mathrm{~g} / \mathrm{mL}(18.67 \mathrm{mM})$ and $0.01 \mathrm{~g} / \mathrm{mL}$ (9.34 mM). At $0.02 \mathrm{~g} / \mathrm{mL}(18.67 \mathrm{mM})$ concentration, the complex showed a good antibacterial effect on the B. cereus, B. subtilis, S. aureus, P. aeruginosa, E. coli and K. pneumoniae. But the cytotoxicity results showed that the rate of death of lymphocyte cells was $93.58 \%$ at same concentration. Similarly, a moderate antibacterial effect occurred at a concentration of $0.01 \mathrm{~g} / \mathrm{mL}$ on all studied bacteria, while MTT test results found $35.23 \%$ cell death. There is no study on the antibacterial activity of zinc 2-fluorobenzoate and its other pyridine derivatives and any of its complexes in the literature. Antibacterial and cytotoxic effects of zinc 2-fluorobenzoate were investigated for the first time in this study.

There are also some studies in the literature that investigate the cytotoxicity of different zinc complexes. For example, Zhu et al. synthesized zinc 2,4,5-benzenetetracarboxylic acid complex with 1,3,5-Tris (1-imidazolyl) benzene and its cytotoxicity was determined by MTT method on HeLa and KB cancer cell lines at the concentrations of 4, 12, 36, 110 and $330 \mu \mathrm{g} \cdot \mathrm{mL}^{-1}$ [30]. In a study conducted with the concentration close to the concentrations in our study, it was reported that zinc complex of Schiff bases derived from o-vanillin was cytotoxic on A549, Hela, HL-60 and K562 cancer cell lines at a concentration of 1\% [31]. Although the complexes synthesized in these studies were suggested as an 
anticarcinogenic agent, their effects on healthy cells at the concentrations studied were not investigated. The results of our study were evaluated as negative, indicating that the tested compound was cytotoxic on the human lymphocyte cell line.

\section{CONCLUSIONS}

In this study, antibacterial and cytotoxic properties of pre-synthesized zinc 2-fluorobenzoate nicotinamide complex were evaluated. The complex showed good activity against Gram positive (B. subtilis, B. cereus and $S$. aureus) and Gram negative (K. pneumonia, P. aerugino$s a$ and $E$. coli) bacteria at $18.67 \mathrm{mM}$ concentration. At the same concentration, the complex was found to exhibit cytotoxic properties. The antibacterial effect of the concentration was found to decrease as the concentration decreased. The cytotoxicity of the complex increases with increasing concentration. The biological activity of the compound becomes insignificant due to increased death in lymphocyte cells at the concentration at which the antibacterial effect increases. In conclusion, when the findings obtained from this study are evaluated, the zinc 2-fluorobenzoate complex with nicotinamide exhibits antibacterial properties and is not recommended as a drug-specific material because it is cytotoxic at the same concentrations.

\section{ACKNOWLEDGEMENT}

This study was produced from the master thesis of the first author. The authors thank to Dr. Cem Öziç and Dr. Füreya Elif Özbek for their supports.

\section{References}

1. Noro S, Miyasaka H, Kitagawa S, Wada T, Okubo T, Yamashita M, Mitani T. Framework Control by a Metalloligand Having Multicoordination Ability: New Synthetic Approach for Crystal Structures and Magnetic Properties. Inorganic Chemistry 44(1) (2005) 133-146.

2. Teo P, Hor TSA. Spacer directed metallo-supramolecular assemblies of pyridine carboxylates. Coordination Chemistry Reviews 255(1-2) (2011) 273-289.

3. Gündüz T. Koordinasyon Kimyası, third ed. Gazi Kitabevi, Ankara, 2005.

4. Yamada K, Yagishita S, Tanaka H, Tohyama K, Adachi K, Kaizaki S, Kumagai $H$, Inoue $K$, Kitaura $R$, Chang HC, Kitagawa S, Kawata S. Metal-Complex Assemblies Constructed from the Flexible Hinge-Like Ligand H2bhnq: Structural Versatility and Dynamic Behavior in the Solid State. Chemistry - A European Journal 10(11) (2004) 26472660.

5. Weiss RB, Christian MC. New cisplatin analogues in development. Drugs 46(3) (1993) 360-377.
6. Sathiyaraj S, Sampath K, Butcher RJ, Pallepogu R, Jayabalakrishnan C. Designing, structural elucidation, comparison of DNA binding, cleavage, radical scavenging activity and anticancer activity of copper(I) complex with 5-dimethyl-2-phenyl-4-[(pyridin-2-ylmethylene)amino]-1,2-dihydro-pyrazol-3-one Schiff base ligand. European Journal of Medicinal Chemistry 64 (2013) 81-89.

7. Uivarosi V. Metal Complexes of Quinolone Antibiotics and Their Applications: An Update. Molecules 18(9) (2013) 11153-11197.

8. Rizzotto M. A search for antibacterial agents, in: Bobbarala V. (Ed.). A search for antibacterial agents. InTech., Crotia, pp. 73-88, 2012.

9. Dimiza F, Papadopoulos AN, Tangoulis V, Psycharis V, Raptopoulou CP, Kessissoglou DP, Psomas G. Biological evaluation of non-steroidal anti-inflammatory drugscobalt(ii) complexes. Dalton Transactions 39(19) (2010) 4517.

10. Dimiza F, Papadopoulos AN, Tangoulis V, Psycharis V, Raptopoulou CP, Kessissoglou DP, Psomas G. Biological evaluation of cobalt(II) complexes with non-steroidal anti-inflammatory drug naproxen. Journal of Inorganic Biochemistry 107(1) (2012) 54-64.

11. Tsiliou S, Kefala LA, Perdih F, Turel I, Kessissoglou DP, Psomas G. Cobalt(II) complexes with non-steroidal antiinflammatory drug tolfenamic acid: Structure and biological evaluation. European Journal of Medicinal Chemistry 48 (2012) 132-142.

12. Zampakou M, Rizeq N, Tangoulis V, Papadopoulos AN, Perdih F, Turel I, Psomas G. Manganese(II) Complexes with the Non-steroidal Anti-Inflammatory Drug Tolfenamic Acid: Structure and Biological Perspectives. Inorganic Chemistry 53(4) (2014) 2040-2052.

13. Dimiza F, Fountoulaki S, Papadopoulos AN, Kontogiorgis CA, Tangoulis V, Raptopoulou CP, Psycharis V, Terzis A, Kessissoglou DP, Psomas G. Non-steroidal antiinflammatory drug-copper(ii) complexes: Structure and biological perspectives. Dalton Transactions 40(34) (2011) 85558568.

14. Fountoulaki S, Perdih F, Turel I, Kessissoglou DP, Psomas G. Non-steroidal anti-inflammatory drug diflunisal interacting with $\mathrm{Cu}(\mathrm{II})$. Structure and biological features. Journal of Inorganic Biochemistry 105(12) (2011) 1645-1655.

15. Tolia C, Papadopoulos AN, Raptopoulou CP, Psycharis V, Garino C, Salassa L, Psomas G. Copper(II) interacting with the non-steroidal antiinflammatory drug flufenamic acid: Structure, antioxidant activity and binding to DNA and albumins. Journal of Inorganic Biochemistry 123 (2013) 53-65.

16. Darawsheh M, Abu Ali H, Abuhijleh AL, Rappocciolo E, Akkawi M, Jaber S, Maloul S, Hussein Y. New mixed ligand zinc(II) complexes based on the antiepileptic drug sodium valproate and bioactive nitrogen-donor ligands. Synthesis, structure and biological properties. European Journal of Medicinal Chemistry 82 (2014) 152-163.

17. Abu Ali H, Darawsheh MD, Rappocciolo E. Synthesis, crystal structure, spectroscopic and biological properties of mixed ligand complexes of zinc(II) valproate with 1,10-phenanthroline and 2-aminomethylpyridine. Polyhedron 61 (2013) 235-241.

18. Abu Ali H, Fares H, Darawsheh M, Rappocciolo E, Akkawi M, Jaber S. Synthesis, characterization and biological 
activity of new mixed ligand complexes of Zn(II) naproxen with nitrogen based ligands. European Journal of Medicinal Chemistry 89 (2015) 67-76.

19. Abu Ali H, Omar SN, Darawsheh MD, Fares H. Synthesis, characterization and antimicrobial activity of zinc(II) ibuprofen complexes with nitrogen-based ligands. Journal of Coordination Chemistry 69(6) (2016) 1110-1122.

20. Özbek FE. 2-Halojenobenzoat Komplekslerinin Sentezi ve Özellikleri. Thesis of Ph.D. Graduate School of Applied and Natural Sciences, Kafkas University (2011) 222 pages.

21. Al-Majidi SMH. Synthesis of some new 4-oxo-thiazolidines, tetrazole and triazole derived from 2-SH-benzothiazole and antimicrobial screening of some synthesized. Journal of Saudi Chemical Society 18(6) (2014) 893-901.

22. Bauer AW, Kirby WMM, Sherris JC, Turck M. Antibiotic Susceptibility Testing by a Standardized Single Disk Method. American Journal of Clinical Pathology 45 (1966) 493-496.

23. Chohan ZH, Supuran CT. Organometallic compounds with biologically active molecules:in vitro antibacterial and antifungal activity of some 1,1'-(dicarbohydrazono) ferrocenes and their cobalt(II), copper(II), nickel(II) and zinc(II) complexes. Applied Organometallic Chemistry 19(12) (2005) 1207-1214.

24. Omar SN, Abu Ali H. New complexes of Zn(II) with the antiinflammatory non-steroidal drug, ibuprofen and nitrogen donor ligands. Synthesis, characterization and biological activity. Journal of Coordination Chemistry 70(14) (2017) 2436-2452.

25. Chiniforoshan H, Tabrizi L, Hadizade M, Sabzalian MR, Chermahini AN, Rezapour M. Anti-inflammatory drugs interacting with $\mathrm{Zn}$ (II) metal ion based on thiocyanate and azide ligands: Synthesis, spectroscopic studies, DFT calculations and antibacterial assays. Spectrochimica Acta Part A: Molecular and Biomolecular Spectroscopy 128 (2014) 183-190.

26. Islas MS, Martínez Medina JJ, Piro OE, Echeverría GA, Ferrer EG, Williams PAM. Comparisons of the spectroscopic and microbiological activities among coumarin-3-carboxylate, o-phenanthroline and zinc(II) complexes. Spectrochimica Acta Part A: Molecular and Biomolecular Spectroscopy 198 (2018) 212-221.

27. Košická P, Gyoryová K, Smolko L, Gyepes R, Hudecová D. Synthesis, crystal structures, spectral, thermal and antimicrobial properties of new Zn(II) 5-iodo- and 5-bromosalicylates. Journal of Molecular Structure 1155 (2018) 232-238.

28. Krajníková A, Gyoryová K, Hudecová D, Kovárová J, Vargová Z. Thermal decomposition and antimicrobial activity of zinc(II) 2-bromobenzoates with organic ligands. Journal of Thermal Analysis and Calorimetry 105(2) (2011) 451-460.

29. Chooset S, Kantacha A, Chainok K, Wongnawa S. Synthesis, crystal structure, luminescent properties and antibacterial activities of zinc complexes with bipyridyl and salicylate ligands. Inorganica Chimica Acta 471 (2018) 493-501.

30. Zhu M, Zhao H, Peng T, Su J, Meng B, Qi Z, Jia B, Feng Y, Gao E. Structure and cytotoxicity of zinc (II) and cobalt (II) complexes based on 1,3,5-tris(1-imidazolyl) benzene: DNA Binding; Fluorescence; anticancer; Apoptosis; Molecular docking. Applied Organometallic Chemistry 33(3) (2019) e4734.

31. Niu MJ, Li Z, Chang GL, Kong XJ, Hong M, Zhang Q. Crystal Structure, Cytotoxicity and Interaction with DNA of Zinc (II) Complexes with o-Vanillin Schiff Base Ligands. PLOS ONE 10(6) (2015) e0130922. 